\title{
Building a Movement to Abolish Prisons: Lessons from the U.S. * Julia Sudbury
}

Tn 1983, a visionary group of activists came together in Toronto, Canada 1 for the First International Conference on Prison Abolition, with the goal of building an international movement to end imprisonment as a response to social problems. Twenty-five years after that first gathering, the prison population globally has exploded. In the U.S. alone, the number of women and men held in cages has grown from around half a million in 1980 to over 2.3 million today. Despite our best efforts, the use of imprisonment as a catch-all solution to social problems - from poverty to addiction - has become more, not less entrenched. It seems like a good time to pause, to celebrate our victories and reflect honestly on our failures, to rethink our strategies and to identify new ways of organizing that may be more effective in the future.

Anti-prison activists in the U.S. are in the midst of this process of reflection. It is ten years since Critical Resistance (CR), an international conference and strategy session was held in Berkeley. The event brought together 3,500 activists, artists, educators, radical lawyers, young people, indigenous people, immigrants, former prisoners and their families, determined to challenge the policing and criminalization of poor communities and communities of colour. CR marked a turning point in abolitionist work in the United States. From that moment, we participated in the growth of a vibrant movement dedicated to building a country and a world without prisons. In September 2008, thousands of people came together in Oakland, California to assess the state of the movement and to explore the challenges we need to overcome to make our vision a reality. The build up to that event included fundraisers, music and poetry events, activist parties, outreach events, documentary film-making and discussion circles across the country. In other words, it was not just about organizing a conference, it was about engaging in an active process of movement building.

Critical Resistance has created a new language to talk about imprisonment, which has become standard in activist, progressive media and academic circles in the United States. Rather than thinking about imprisonment as a response to crime, we began to explore the ways in which prisons had become embedded in the political and economic landscape, creating numerous interest groups - from politicians to private prison contractors - who profit from and are dedicated to continuing mass incarceration. We 
argued that since prisons clearly do not create safety or prevent crime - and the U.S. has to be the perfect case study for that reality - then the massive prison expansion we have been witnessing must exist for some other function. We found that function in the prison-industrial complex (PIC) - a symbiotic relationship between politicians, corporations, the media and government. This symbiotic entity generates mass racialized incarceration as a supposed solution to the social problems caused by globalization and the state's retreat from social welfare. A so-called solution, which of course only exacerbates the problems it claims to resolve, therefore perpetuating its own existence.

A classic example of this is the war on drugs, which has hugely increased the number of people in prison - in particular African Americans and Latinos - while draining public funds, which could have been used to fund treatment and to tackle the social problems leading to drug use. In East Oakland, where I live, incarcerated people with addictions are released with little to no recovery, into a community devastated by racism, poverty, violence and drugs - a situation rooted in three decades of neoliberal economic reforms - and then recycled back into the system when they relapse. Even in states like California which have passed laws mandating drug treatment rather than prison for certain drug offences, the criminal justice system remains the gatekeeper to drug treatment, ensuring that low-income drug users, particularly people of colour will continue to keep the prison beds filled and the prison machine generating profits.

The concept PIC makes visible the money involved in the prison buildup, where it comes from and whose pocket it ends up in. It is therefore a powerful basis for mobilizing opposition by everyone who believes that their taxes should be building schools, hospitals, youth programs, treatment centers and women's shelters, not warehousing people in cages. In other words, it is a powerful coalition-building tool. The PIC also shifts our focus from prisons to the entire web of policing, control and state violence that assaults poor communities and communities of colour everyday. This is the reason that many activists in the U.S. have shifted from talking about prison or penal abolition to PIC abolition. Critical Resistance's vision of PIC abolition is as follows:

We work for PIC abolition because we do not believe that any amount of imprisonment, policing, or surveillance will ultimately make our 
communities safer or more self-determined, prevent "crime", or help repair the damage that happens when one person hurts another. We believe, instead, that access to basic necessities like food, shelter, meaningful work and freedom as well as alternative systems of accountability create the conditions for healthier, more stable neighborhoods, families, and our wider communities

- http://www.criticalresistance.org/downloads/cr10_pamphlet1.pdf

PIC Abolition is not about creating alternatives to incarceration, it is about social and economic justice. That means that we cannot simply dismantle prisons, jails and detention centres, we must also build self-determining communities that are fully resourced to meet their members' needs. This is why the theme of CR10 is Dismantle, Change, Build. To create a world where prisons are obsolete - to quote Angela Davis (2003) - we must also change the inequalities that cause harm at interpersonal and institutional levels, and build a society governed by the principles of social and economic justice. Put simply, a world without prisons is also a world with safe affordable housing, good nutrition, healthcare, a quality education, and opportunities for creativity and healing for all. Put even more simply, a world in which everyone is valued enough to be treated as a human being, cannot also contain the violence and separation of imprisonment.

\section{Lessons}

I want to briefly share some lessons from our movement assessment process and from my own experiences of abolitionist organizing during the past ten years. I identified 10 lessons.

\section{A Movement vs. a Non-profit}

The first lesson we have learned is the critical importance of building a mass movement. A movement is not a non-profit or voluntary organization, although these may contribute by providing infrastructure and staffing helpful to movement work. The radical women of colour organization, Incite!, recently published a book called The Revolution Will Not Be Funded, which pointed out the fundamental error in thinking that the non-profit model of organizing can ever bring about radical social change. Voluntary organizations can and do influence government policies, but they cannot generate the people-power 
necessary to create the kind of fundamental social and economic reorganization necessary to make prisons obsolete. Abolitionist Dylan Rodriguez argues that alongside the PIC, we now have a non-profit industrial complex that manages and controls dissent, turning grassroots discontent into policy papers and consultation meetings palatable to the state. This non-profit model of social change limits grassroots mobilizing because it tends to produce paid experts who are seen as having more legitimacy than directly affected communities. But as Arundhati Roy (2004) says: "Real resistance has real consequences. And no salary". To confront state violence, in the form of the overpolicing and criminalization of poor communities, we need a mass mobilization similar to the mobilizations against the war in Iraq. Only then will we begin to see real change.

\section{Beyond "Preaching to the Choir"}

I am calling the second lesson: 'beyond preaching to the choir'. Often as anti-prison organizers we find ourselves speaking to each other at small gatherings of like-minded people. If we are going to build a mass movement however, we need more than a couple hundred dedicated abolitionists. CR has worked to mobilize large numbers of people by reaching out to people who might not initially oppose prisons. For example, many African Americans from low-income communities feel that the criminal justice system is the only thing between them and the chaos of drugs and gun violence. At the same time, most will have at least one loved one who has been in conflict with the law, and they also experience overpolicing and harassment. CR has shifted people toward embracing abolition in these communities by creating conversations about what the community would need to feel safer - whether after school programs, better lighting, cleaned up parks and so on - and then asking how people would spend the billions of dollars it costs to incarcerate people from these communities. We need to get out of our comfort zones, and talk abolition in immigrant communities, unions, classrooms and elsewhere. We also need to demonstrate that we are all impacted by the PIC and we all have a stake in dismantling it.

\section{Thinking through Race, Class, Gender and Nationality}

The third lesson is the importance of putting an analysis of the intersections of race, class, gender and nationality at the center of our work. This means that we need to understand the ways in which our activist spaces 
can mirror the systemic inequalities that fuel the PIC. For example, who are our spokespersons? Do they include formerly incarcerated people? Black people? Queer and trans people? Immigrants? Refugees? Or are we replicating the prison system, with white middle class activists acting as 'movement wardens'? Are we speaking about people in prison and their communities, or are directly affected communities speaking for ourselves?

\section{Leadership by the Most Affected}

The fourth lesson is that prioritizing the voices of incarcerated and formerly incarcerated people, along with the most affected communities involves mindfulness and proactivity. Much of our organizing involves using email. How does this impact recently released members who may not have a computer easily available? Where are our gatherings located and how accessible are these spaces to low-income communities of colour? What are the dynamics of our meetings? Do university-educated members know when to step back and create space for others to speak? Those of us who have class and race privilege can support initiatives like the Leadership Training Institute which trains recently released women in public speaking and organizing, and All of Us or None, a civil rights organizations for former felons in the U.S. to develop new leadership for movement.

\section{Mobilizing Youth}

The fifth lesson is that any movement that is going to be vibrant and create lasting change must involve the mobilization of young people. In the U.S., young people have taken the lead in the abolitionist movement. At the first CR conference, over 2,000 school children staged a walk out to demand that a new youth jail not be built. Young people as well as educators have organized under the banner of education not incarceration, as well as denouncing the school-to-prison-pipeline. These campaigns have brought together teachers unions, young people, parents and abolitionists to challenge education cutbacks, fee increases, school exclusions, and school closures, as well as to make the link between spending on policing and prisons, and cuts to education.

\section{Art as a Tool of Resistance}

The sixth lesson is the importance of the arts and culture, in particular music. Music has always been an important part of the new abolitionist movement 
in the U.S.. The hip hop movement - and underground or grassroots hip hop in particular - can carry a political message in a far more powerful way than any talk or paper. At CR events, we've had the support of international popular musicians such as M'shel Ndegeochello and Mos Def. But possibly more importantly, local artists, musicians, youth dancers, and others have created artistic work that expresses a radical abolitionist vision and uses art as a vehicle for social change.

\section{Spirituality, Healing and Recovery}

The seventh lesson is the importance of incorporating spirituality, healing and recovery into our movement work. When we organized the first CR, the organizers really abandoned our own well-being for the good of the movement. After the event, we were burnt out and many of us were in relationship break-ups! We have learned that that is not a sustainable way to organize. We also know that the PIC is a violent and brutalizing system, so if we want to include those directly affected by it, we need to make space for people to heal from the violence. At CR10, we had AA and NA meetings, yoga and meditation, a healing space, counsellors and body movement workshops. We also had an interfaith breakfast, where people from different faith backgrounds explored what it means to bring their spirituality to the work. This is very different from the missionary work of early abolitionists who were dedicated to helping others. It is about using spirituality as a source of strength in our efforts to liberate ourselves and our communities.

\section{Cross-movement Coalitions}

The eighth lesson is the importance of building cross-movement coalitions. In the U.S., abolitionist spaces include those whose primary focus is organizing against the war, globalization and domestic violence, for immigrant and indigenous rights, economic and environmental justice, sexworker rights, Palestinian solidarity, the military out of Puerto Rico and so on. In this way, we infuse abolitionist politics into all of our progressive movements. As we do so, we also need to work on building a shared analysis, so that we can avoid undermining each other's work. For example, we need to ensure that those working against the criminalization and detention of Arabs and Middle Eastern communities do not use the rhetoric that "they do not belong in prison", suggesting implicitly that 
black and poor people do belong in prison. Similarly, we need to make sure that black communities understand how the war in Iraq is tied to the policing of black communities at home.

\title{
The Transnational PIC
}

The ninth lesson is the need for global analysis and coalition-building. Although there is a long history of internationalist organizing in the U.S., many activists struggle to see beyond U.S. borders. In the past decade, however, it has become clear that the PIC is transnational, with crossborder links existing between corporations and pro-prison politicians in the U.S., Canada, Mexico, Central America, Europe, Iraq, Afghanistan and elsewhere. Like a many-headed hydra, if we cut off the head in one country, it can re-emerge and flourish in another. This is what happened when private prison corporations that were beginning to struggle in the U.S. spread to South Africa and Europe. That is why ICOPA is such an important forum in challenging the transnational PIC.

\begin{abstract}
Abolition NOW
Our final lesson is that we can and must live abolition NOW. Abolition is a way of living and organizing in our families, communities and work, not just a vision of the future. Living abolition means re-examining our everyday assumptions about how to deal with conflict and harm in our lives. It means seeking transformative approaches to create accountability in our lives. Organizations like Creative Interventions in the U.S. have started to build alternative forms of community accountability, rooted in gender and racial justice that we can use right now. We may know a family member who is violent or a member of an organization who is sexually harassing another member. Community accountability strategies encourage us to take responsibility for tackling harm collectively, in ways that honour all involved. Living abolition also means challenging the systemic inequalities that the PIC is built on in our everyday lives. This might mean examining how race or class privilege operates in our lives and in our organizing, and taking action to create more horizontal relationships. Ultimately the promise of abolition is that we can live a life without blaming, punishing or inflicting violence. And that is a life we can live right now.
\end{abstract}




\section{ENDNOTES}

* An earlier version of this piece was presented at the Twelfth International Conference on Penal Abolition which took place in July 2008 at King's College London, England.

\section{REFERENCES}

Davis, Angela Y. (2003) Are Prisons Obsolete?, New York: Seven Stories Press.

Roy, Arundhati (2004) Public Power in the Age of Empire, New York: Seven Stories Press.

\section{About the Author}

Julia Sudbury is a leading activist scholar in the prison abolitionist movement. She was a co-founder of Critical Resistance - www.criticalresistance.org, a national abolitionist organisation that popularised the concept of the "prisonindustrial complex" in the United States. She is now Professor of Ethnic Studies at Mills College, a women's liberal arts college in California. 